\title{
Meiotic Behavior and Pollen Viability of Spondias mombin L.: Native Fruit Species of the Amazon
}

\author{
Kelli Évelin Müller Zortéa ${ }^{1,2}$ (D), Ana Aparecida Bandini Rossi ${ }^{1,2,3}$, \\ Rosimeire Barboza Bispo ${ }^{4}$ (D), Vinícius Delgado da Rocha ${ }^{5}$, \\ Eulalia Soler Sobreira Hoogerheide ${ }^{6}$
}

${ }^{1}$ Programa de Pós-graduação em Biodiversidade e Biotecnologia da Rede Bionorte, Universidade do Estado de Mato Grosso Carlos Alberto Reyes Maldonado - UNEMAT, Alta Floresta/MT, Brasil

${ }^{2}$ Programa de Pós-graduação em Genética e Melhoramento de Plantas, Universidade do Estado de Mato Grosso Carlos Alberto Reyes Maldonado - UNEMAT, Alta Floresta/MT, Brasil

${ }^{3}$ Programa de Pós-graduação em Biodiversidade e Agroecossistemas Amazônicos, Faculdade de Ciências Biológicas e Agrárias, Universidade do Estado de Mato Grosso Carlos Alberto Reyes Maldonado - UNEMAT, Alta Floresta/MT, Brasil

${ }^{4}$ Programa de Pós-graduação em Biotecnologia Vegetal, Universidade Estadual do Norte Fluminense Darcy Ribeiro UENF, Campos dos Goytacazes/RJ, Brasil

${ }^{5}$ Programa de Pós-graduação em Genética e Melhoramento, Universidade Federal de Viçosa - UFV, Viçosa/MG, Brasil ${ }^{6}$ Embrapa Agrossilvipastoril, Sinop/MT, Brasil

\begin{abstract}
Spondias mombin L. is a fruit species native to the Amazon with great marketing potential. The aim of this study was to examine the meiotic behavior and pollen viability of S. mombin. Flower buds at various developmental stages were collected for analyses of pollen viability, in vitro germination, and meiotic behavior. S. mombin is diploid with $2 \mathrm{n}=2 \mathrm{x}=30$ chromosomes. Meiosis showed to be regular, with only $13.3 \%$ of cells with abnormal division. A high meiotic index was found: $96.5 \%$. Pollen viability did not differ between male $(96.3 \%)$ and bisexual (96.7\%) flowers, and the overall mean of viable pollen was considered high (96.5\%). Pollen germination occurred in all tested media, with the treatment containing $20 \%$ sucrose and $50 \mathrm{mg}$ $\mathrm{mL}^{-1}$ boric acid being the most suitable. The highest pollen germination means occurred after $36 \mathrm{~h}$ of incubation. The obtained information can be used in the planning and implementation of commercial crops of the species.
\end{abstract}

Keywords: cajá, pollen fertility, pollen germination, meiotic index. 


\section{INTRODUCTION}

The genus Spondias belongs to the family Anacardiaceae, where it stands out for comprising important fruit species that are economically exploited in tropical and subtropical regions of the world. One of such species is Spondias mombin L., popularly known in Brazil as cajazeira or taperebá (Mitchell \& Daly, 2015). The fruit of S. mombin has great market value, especially in north and northeast Brazil, where it occupies a prominent place in pulp production (Cassimiro et al., 2009). Spondias mombin L. contains elevated levels of potassium, magnesium, phosphorus, copper, phenolic compounds, antioxidants, and carotenoids when compared with other fruits (Mattietto et al., 2010; Tiburski et al., 2011). Its composition therefore provides it with elevated nutritional and functional value, which can be associated with the prevention of various diseases (Tiburski et al., 2011)

The increasing demand for $S$. mombin has aroused the interest in cultivating this species, which is considered to still be under domestication (Cassimiro et al., 2009). Fruit production in S. mombin is achieved through extractivism and from domestic orchards, resulting in annual variations in the harvests that influence the pulp processing industry and its market demands (Oliveira et al., 2012). The little knowledge and inexistent information about S. mombin and its entire production chain hinder the development of a production system (Souza et al., 2006). In this regard, there is a need for information that contributes to the establishment of commercial orchards able to maintain production and meet the market demands, including the reproductive aspects of this species.

Reproduction is one of the main pillars for the maintenance of an economically viable crop, whether through vegetative or sexual propagation (Silva \& Pinheiro, 2007). Knowledge about the reproduction aspects of a plant contributes to the implementation of production systems, breeding programs, and conservation practices (Zen \& Acra, 2005; Pozzobon et al., 2015). In sexually reproducing species, the pollen grain is responsible for transporting the male gamete to the stigma in the female flower (Agostini et al., 2014), playing a key function in the reproduction program and in the productivity of a plant (Arenas-de-Souza et al., 2014; Oliveira \& Maruyama, 2014). In this way, the crop yield is usually dependent on viable pollen grains (Patel \& Mankad, 2014).

The pollen grain originates from meiosis, an integrated and highly coherent process controlled by a large number of genes. It can be affected by the presence of mutant genes, which induce the formation of abnormal products (Pagliarini, 2000; Martins et al., 2010a). Abnormalities in meiosis can lead to the formation of gametes with an unbalanced chromosome number, usually inviable, and to low plant yield (Nascimento et al., 2014b).

Spondias mombin is very important for the growth of the Brazilian fruit market, but little information exists on the reproductive aspects of this species. Given this scenario, the present study was proposed to evaluate the meiotic behavior and pollen viability of $S$. mombin to generate knowledge for the implementation of crops, genetic breeding programs, and conservation of the species.

\section{MATERIAL AND METHODS}

Flower buds of S. mombin at different developmental stages were collected from individuals located in the municipality of Alta Floresta, extreme north of Mato Grosso State, Brazil. The material was fixed in absolute ethyl alcohol and glacial acetic acid solution $(3: 1 \mathrm{v} / \mathrm{v})$ at the time of collection and transferred to $70 \%$ alcohol after $24 \mathrm{~h}$, kept under refrigeration.

The meiotic behavior of $S$. mombin was assessed by counting meiotic cells obtained from flower buds of 10 individuals collected in bulk. To prepare the slides, anthers were separated and slightly macerated under a drop of $2 \%$ acetocarmine stain (Guerra \& Souza 2002). Slides were observed under a binocular microscope (Photonics Bio 2 LED - BEL) with a 40x lens. The different meiotic stages were analyzed and irregularities were counted.

Young buds from eight $S$. mombin individuals were used to estimat the meiotic index. Two thousand post-meiotic products were counted per individual. Tetrads with the four cells of the same size were considered normal, and any deviation (monads, dyads, triads, and polyads) were considered abnormal. The meiotic index was calculated according to Love (1951), following formula 1: 
$\mathrm{MI}=\frac{\text { Total } \mathrm{n} \text { of normal post-meiotic products }}{\text { Total } \mathrm{n} \text { of normal and abnormal post-meiotic products }} \times 100$

Pollen viability was estimated via colorimetric test in male and bisexual flower buds of eight individuals pre-anthesis, separately, to check for significant statistical differences between floral types and between individuals. Anthers were separated and slightly macerated onto slides under a drop of Alexander's triple solution. Pollen grains were classified as viable or inviable according to the staining, with viable pollen stained red/purple and inviable pollen stained green (Alexander, 1980). A total of 2,000 pollen grains were counted per floral type and 4,000 were counted per individual. Viability data were transformed into percentage terms.

For the in vitro germination assay, we used pollen from fresh flower buds in pre-anthesis of three S. mombin individuals collected on the same day, in the afternoon. Eight liquid growth media were tested: T1 - 0\% sucrose and $0 \mathrm{mg} \mathrm{mL}^{-1}$ boric acid; $\mathrm{T} 2$ - $0 \%$ sucrose and $50 \mathrm{mg} \mathrm{mL}^{-1}$ boric acid; $\mathrm{T} 3$ - $5 \%$ sucrose and $0 \mathrm{mg} \mathrm{mL}^{-1}$ boric acid; $\mathrm{T} 4$ - $5 \%$ sucrose and $50 \mathrm{mg} \mathrm{mL}^{-1}$ boric acid; T5 - 10\% sucrose and $0 \mathrm{mg} \mathrm{mL}^{-1}$ boric acid; T6 - 10\% sucrose and $50 \mathrm{mg} \mathrm{mL}^{-1}$ boric acid; T7 - 20\% sucrose and $0 \mathrm{mg} \mathrm{mL}^{-1}$ boric acid; and T8 - 20\% sucrose and $50 \mathrm{mg} \mathrm{mL}^{-1}$ boric acid. Germination was evaluated at three incubation times: 12,24 , and $36 \mathrm{~h}$. The growth media were distributed onto 60 -cm-thick acrylic plates on which the pollen was deposited. Plates were maintained in a B.O.D. (Biochemical Oxygen Demand) incubator at a temperature of $25^{\circ} \mathrm{C}\left( \pm 2^{\circ} \mathrm{C}\right)$, in the dark.

The experiment was set up as a completely randomized design with an $8 \times 3$ factorial arrangement ( $8=$ treatments; $3=$ times $)$ with four replicates. A total of 250 pollen grains were counted per replicate in each treatment and at each counting time. Pollen grains were considered germinated when the pollen tube reached or exceeded its diameter (Reis et al., 2011). The percentage of germinated pollen grains was obtained by the following formula 2 :

Germination $\%=\frac{\mathrm{N} \text { of germinated pollen grains }}{\text { Total } \mathrm{n} \text { of counted pollen grains }} \times 100$

Pollen tube length was measured in ten pollen tubes from each treatment, which were selected at random after $36 \mathrm{~h}$ of incubation. Pollen grains were photographed with a CMOS 1.3 camera coupled to the microscope, using the Tsview 1.0.0.1. image capture system. Measurements were taken using ANATI QUANT software version 2.0.

The MI and pollen viability data obtained by the colorimetric test were subjected to analysis of variance and significant means were compared by Tukey's test $(\mathrm{P}<0.05)$. In vitro germination percentage data were transformed using $\arcsin \sqrt{\frac{\mathrm{X}}{100}}$ and then subjected to analysis of variance. Significant means were compared with each other via Scott-Knott test at a probability level of 5\%. Statistical analyses were performed using Genes software (Cruz, 2013).

\section{RESULTS AND DISCUSSION}

The meiotic analysis of the S. mombin individuals allowed to observe 15 chromosomes in a bivalent association, corroborating with the chromosome number found by Macêdo (2011) for the specie $(2 \mathrm{n}=2 \mathrm{x}=30)$ (Figure 1A).

Meiosis in S. mombin was regular, because of the 837 cells analyzed only $13.3 \%$ cells presented irregularities. Among the irregularities, $14.4 \%$ consisted of chromosomes out off the equatorial plate, during metaphase I (Figure 1B); $9.9 \%$ of delayed/early chromosomes in anaphase (Figure 1C); 62.1\% under asynchronous division (Figure 1D); and 13.5\% under lack of spindle fiber orientation (Figure 1E). Patterns of similar irregularities were found by Martins et al. (2010b) studying the meiotic behavior of different species of Capsicum, by Souza \& Pereira (2011) in Passiflora species, and by Damasceno et al. (2010) in studies of the meiosis of Carica papaya L. and Vasconcellea monoica.

Cells with asynchronous division occurred more frequently, which was observed when both nuclei in meiosis II did not reach the same stage simultaneously and were found in different stages. This irregularity was also reported by Martins et al. (2010b) as the most common in the meiosis of different species of Capsicum.

Delayed and early chromosomes off the equatorial plate were observed in metaphase and anaphase I. This abnormality may originate micronuclei in meiosis II (Kiihl et al., 2010) and in the post-meiotic products, associated with the formation of unbalanced gametes and consequent formation of inviable gametes (Nascimento et al., 2014a). No micronuclei were 
observed in S. mombin. However polyads were detected with a reduced cell in relation to the others, in $0.4 \%$ of post-meiotic products (Figure $1 \mathrm{~F}$ ), which may be related to the chromosomes found off the equatorial plate.

The lack of spindle fiber orientation was characterized by the presence of aligned chromosomes on the equatorial plate forming a $\mathrm{T}$ shape; i.e., on a transverse spindle (Figure 1E). This abnormality was described by Shamina (2005), who considered it responsible for the tripolar chromosomal segregation. As stated by Souza et al. (2014), irregular orientation of spindle fibers may compromise the normal chromosomal segregation, possibly generating abnormal post-meiotic products such as triads, dyads, monads, and polyads. Thus, the abnormalities observed in the meiosis of S. mombin explain the abnormal post-meiotic products found.

Although the meiotic abnormalities directly influenced the post-meiotic products, the abnormalities observed in S. mombin did not considerably hinder the formation of post-meiotic products of the species, since it showed a MI of $96.5 \%$ (Table 1) and, according to Love (1951), plants with a MI greater than $90 \%$ have high meiotic stability. The eight $S$. mombin individuals analyzed showed statistically different meiotic indices, but despite this difference, all individuals had a MI higher than 95\% (Table 1). The abnormality found at highest frequency consisted of triads (Table 1, Figure $1 \mathrm{G}$ ) and is related to the type of abnormalities encountered during meiosis.
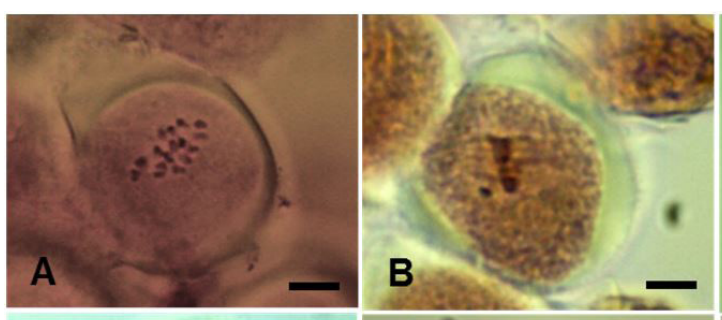

E
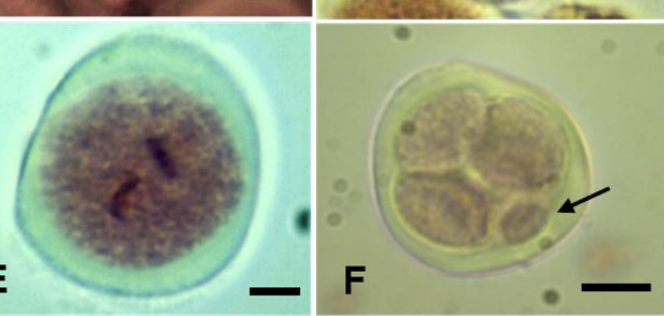
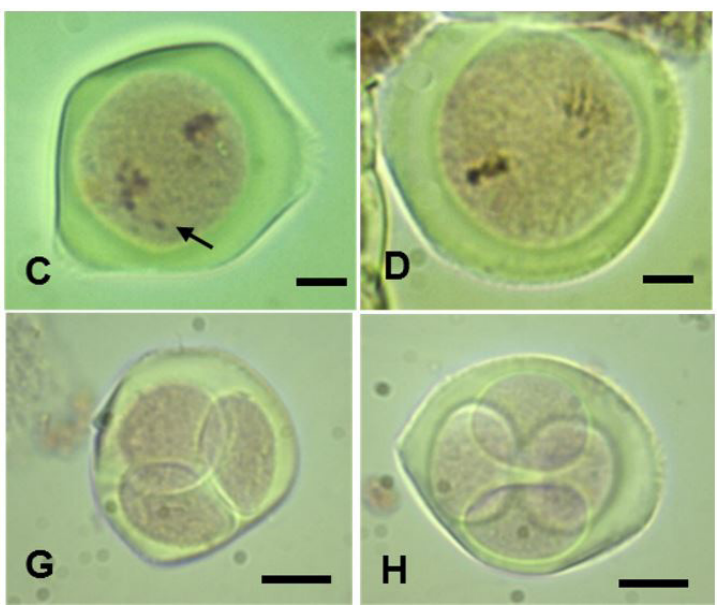

Figure 1. Meiosis stages and post-meiotic products of S. mombin. A) Prophase I; B) Metaphase I with delayed chromosome; C) Asynchronous division with one early chromosome (arrow); D) Asynchronous division; E) Metaphase II with chromosomes aligned in a " $T$ ” form; F) Polyad presenting one of the cells reduced (arrow); G) Triad; H) Normal tetrad. Scale of A to $E=10 \mu \mathrm{m}$; Scale of F to $\mathrm{H}=20 \mu \mathrm{m}$.

Table 1. Post-meiotic products and Meiotic Index (MI) observed in S. mombin.

\begin{tabular}{|ccccccc|}
\hline Individual & Tetrads & Monads & Dyads & Triads & Polyads & MI (\%) \\
\hline 1 & 1,936 & 0 & 0 & 54 & 10 & $96.8 \mathrm{abc}$ \\
\hline 2 & 1,960 & 0 & 0 & 30 & 10 & $98.0 \mathrm{ab}$ \\
3 & 1,969 & 0 & 0 & 22 & 9 & $98.4 \mathrm{a}$ \\
4 & 1,910 & 1 & 1 & 85 & 3 & $95.5 \mathrm{c}$ \\
\hline 5 & 1,912 & 4 & 1 & 76 & 7 & $95.6 \mathrm{c}$ \\
6 & 1,935 & 3 & 0 & 61 & 22 & $96.7 \mathrm{abc}$ \\
\hline 7 & 1,906 & 19 & 0 & 53 & 1 & $95.3 \mathrm{c}$ \\
\hline 8 & 1,916 & 6 & 2 & 458 & 63 & 16,000 \\
\hline Total & 15,444 & 33 & 0.2 & 57.2 & 7.9 & 96.5 \\
\hline Mean & $1,930.5$ & 4.1 & & & & \\
\hline
\end{tabular}

Means followed by the same letter do not differ by Tukey's test $(p<0.05)$. 
The analyzed individuals displayed significantly different pollen viabilities across them, as shown in the analysis of variance (Table 2). According to Santos et al. (2006) and Zanotto et al. (2009), pollen viability may have considerable variations both between individuals of the same species and between samples of the same individual. Flowering period (Dafni, 1992), flower longevity (Arenas-de-Souza et al., 2014), environmental alterations (Jesus et al., 2018), and genotypic differences (Pozzobon et al., 2015; Diegues et al., 2015) can contribute to this variation. Therefore, to evaluate male fertility, it is important that population studies with distinct samples be carried out (Hoffmann \& Varassin, 2011), as is the case of the present work.

There was no significant statistical difference for the pollen viability of the floral types, indicating that both types contribute with viable pollen for reproduction

Table 2. Mean percentage pollen viability in S. mombin per floral type estimated via colorimetric test with Alexander's triple solution.

\begin{tabular}{|c|c|c|c|}
\hline Individual & $\begin{array}{c}\text { Male } \\
\text { flower }\end{array}$ & $\begin{array}{c}\text { Bisexual } \\
\text { flower }\end{array}$ & $\begin{array}{c}\text { Mean in } \\
\text { both floral } \\
\text { types }\end{array}$ \\
\hline 1 & $96.1 \mathrm{ab}$ & $97.5 \mathrm{a}$ & $96.8 \mathrm{ab}$ \\
\hline 2 & $96.8 \mathrm{ab}$ & $96.9 \mathrm{ab}$ & $96.9 \mathrm{ab}$ \\
\hline 3 & $97.0 \mathrm{ab}$ & $96.4 \mathrm{ab}$ & $96.7 \mathrm{abc}$ \\
\hline 4 & $97.1 \mathrm{ab}$ & $98.4 \mathrm{a}$ & $97.8 \mathrm{a}$ \\
\hline 5 & $94.8 \mathrm{ab}$ & $93.6 \mathrm{~b}$ & $94.2 \mathrm{c}$ \\
\hline 6 & $98.1 \mathrm{a}$ & $97.5 \mathrm{a}$ & $97.8 \mathrm{a}$ \\
\hline 7 & $95.4 \mathrm{ab}$ & $97.3 \mathrm{a}$ & $96.3 \mathrm{abc}$ \\
\hline 8 & $94.5 \mathrm{~b}$ & $95.8 \mathrm{ab}$ & $95.1 \mathrm{bc}$ \\
\hline Mean & 96.3 & 96.7 & 96.5 \\
\hline CV (\%) & & & 2.38 \\
\hline
\end{tabular}

Means followed by the same letter do not differ by Tukey's test $(\mathrm{p}<0.05)$.
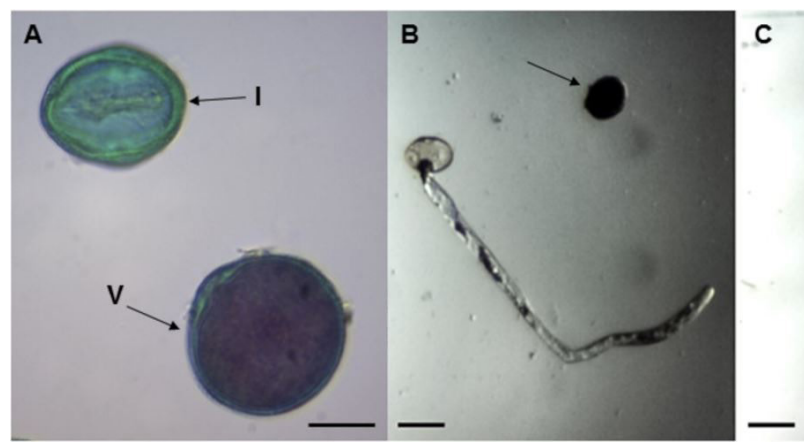

(Table 2). Similar results were found by Nadia et al. (2007), who estimated the pollen viability of Spondias tuberosa Arruda and detected that viability did not differ between male and bisexual flowers.

Pollen viability in S. mombin was considered high, with values greater than $90 \%$ in all individuals assessed and an average of $96.5 \%$, comprising all individuals and both floral types (Table 2, Figure 2A). According to Souza et al. (2002) and Hister \& Tedesco (2016), pollen viability rates greater than $70 \%$ can be considered high. A similar finding was reported by Nadia et al. (2007), who described pollen viability higher than $90 \%$ in Spondias tuberosa.

The growth media evaluated in this study enabled the pollen germination of S. mombin (Figure 2B-D). There was a significant interaction effect between treatments (media) and incubation periods on pollen germination (Table 3 ). Time positively influenced pollen germination: in treatments T2, T4, T7, and T8, the highest percentage of germinated pollen was found at $36 \mathrm{~h}$ (Table 3). Overall, all means were higher in the period of $36 \mathrm{~h}$, despite not differing statistically from the other incubation periods in all treatments. According to Gaaliche et al. (2013), the highest in vitro pollen germination percentages are obtained in prolonged incubation periods, which was confirmed in this study for S. mombin.

Treatments T4 and T8 presented the best germination means after $36 \mathrm{~h}$ of incubation. Both treatments contained sucrose and boric acid. Although the germination mean of T8 did not differ statistically from that of T4 at $36 \mathrm{~h}$, the latter showed a higher mean germination percentage.

Figure 2. Pollen of S. mombin. A) Viable (V) and inviable (I) pollen grain stained with Alexander's triple solution $($ scale $=30 \mu \mathrm{m})$; B) In vitro germination showing a germinated and an ungerminated (arrow) pollen grain; C and D) Pollen tube development stages (scale $=50 \mu \mathrm{m})$. 
Table 3. Mean in vitro pollen germination percentage of S. mombin under different treatments and incubation periods.

\begin{tabular}{|c|c|c|c|c|}
\hline \multirow{2}{*}{ Treatment } & \multicolumn{3}{|c|}{ Incubation period } & \multirow{2}{*}{$\begin{array}{l}\text { PTL }(\mu \mathrm{m}) \\
\text { after } 36 \mathrm{~h}\end{array}$} \\
\hline & $12 \mathrm{~h}$ & $24 \mathrm{~h}$ & $36 \mathrm{~h}$ & \\
\hline $\mathrm{T} 1$ (0\% $\mathrm{S}$ and $0 \mathrm{mg} \mathrm{BA})$ & $26.1 \mathrm{Aa}$ & $34.4 \mathrm{Ab}$ & $32.8 \mathrm{Ac}$ & $171.0 \mathrm{~b}$ \\
\hline $\mathrm{T} 2(0 \% \mathrm{~S}$ and $50 \mathrm{mg} \mathrm{BA})$ & $16.5 \mathrm{Ba}$ & $27.1 \mathrm{Bb}$ & $80.5 \mathrm{Ab}$ & $277.4 \mathrm{a}$ \\
\hline $\mathrm{T} 3$ (5\% $\mathrm{S}$ and $0 \mathrm{mg} \mathrm{BA}$ ) & $27.1 \mathrm{Aa}$ & $23.4 \mathrm{Ab}$ & $30.1 \mathrm{Ac}$ & $239.0 \mathrm{ab}$ \\
\hline $\mathrm{T} 4$ (5\% $\mathrm{S}$ and $50 \mathrm{mg} \mathrm{BA})$ & $22.4 \mathrm{Ba}$ & $34.4 \mathrm{Bb}$ & $89.5 \mathrm{Aa}$ & $276.2 \mathrm{a}$ \\
\hline T5 (10\% S and $0 \mathrm{mg} \mathrm{BA})$ & $19.3 \mathrm{Aa}$ & $25.4 \mathrm{Ab}$ & $26.4 \mathrm{Ac}$ & $250.3 \mathrm{a}$ \\
\hline T6 (10\% $\mathrm{S}$ and $50 \mathrm{mg} \mathrm{BA})$ & $18.4 \mathrm{Aa}$ & $25.3 \mathrm{Ab}$ & $27.1 \mathrm{Ac}$ & $310.4 \mathrm{a}$ \\
\hline T7 (20\% S and $0 \mathrm{mg} \mathrm{BA})$ & $21.6 \mathrm{Ba}$ & $31.0 \mathrm{Bb}$ & $74.8 \mathrm{Ab}$ & 259.9 a \\
\hline T8 (20\% $\mathrm{S}$ and $50 \mathrm{mg} \mathrm{BA})$ & $38.1 \mathrm{Ca}$ & $54.8 \mathrm{Ba}$ & $95.3 \mathrm{Aa}$ & $311.6 \mathrm{a}$ \\
\hline CV (\%) & & 18.42 & & 21.53 \\
\hline
\end{tabular}

Means followed by the same uppercase letter in the row and lowercase letter in the column do not differ by the Scott-Knott test $(\mathrm{p}<0.05) . \mathrm{S}=$ sucrose; $\mathrm{BA}=$ boric acid; $\mathrm{PTL}=$ pollen tube length.

The pollen tube length of S. mombin was influenced by the treatments (Table 3). Treatment T1, consisting of distilled water only, provided the lowest average length and was statistically different from the other treatments which contained only sucrose or sucrose combined with boric acid. This result indicates that the presence of these components contributes to the growth of the pollen tube. Sucrose has the function of providing energy for the development of the pollen tube and promoting osmotic balance between the growth medium and the pollen (Santos et al., 2011; Zambon et al., 2014). Boric acid stimulates the growth of the pollen tube and prevents it from breaking (Frazon et al., 2006).

The most suitable treatment for germination of S. mombin pollen in this study (T8) contained boric acid and the highest sucrose concentration tested (20\%). All treatments in which boric acid or sucrose were present showed a significantly higher average pollen tube length than treatment $\mathrm{T} 1$, which did not have these components, suggesting that boric acid and sucrose improved the germination conditions in S. mombin. Patel \& Mankad (2014) declared that germination and pollen tube growth increase as the concentration of boric acid is elevated. Nogueira et al. (2015) submitted that boric acid addition increases the efficiency of sucrose both in germination and in the growth of the pollen tube.

Viability data obtained by in vitro germination confirm the results of the colorimetric test. In both tests, viability was greater than $90 \%$, considering the most suitable growth medium among those under evaluation (T8).
Plant fertility depends on meiotic regularity during the formation of pollen grains (Pereira et al., 2017). The regularity and meiotic stability of S. mombin is reflected on the high pollen viability of the species, estimated both by the colorimetric test and in vitro pollen germination.

According to Souza et al. (2006), S. mombin produces a large number of flowers, but only a few are fertilized and generate fruits, which is in general due to climatic factors such as winds, high temperature, low humidity, and physiological factors that cause flower abscission. These authors also found that pollinated flowers seldom undergo abscission; i.e., fertilization ensures the production of a new fruit. This characteristic confirms the meiotic stability and pollen viability found in this study, demonstrating that the pollen grains that reach the stigma are able to fertilize the ovule.

\section{CONCLUSION}

The species $S$. mombin showed great stability and meiotic regularity. Due to regular meiosis, pollen viability was high in the tested methods. This characteristic is import to reproductive success of the species.

For the evaluation of pollen viability in vitro of $S$. mombin, it is recommended the use of liquid germination medium constituted of $20 \%$ sucrose and $50 \mathrm{mg} \mathrm{mL}^{-1}$ boric acid, besides incubation for 24 to $36 \mathrm{~h}$ in the incubator B. O. D with temperature of $25^{\circ} \mathrm{C}\left( \pm 2{ }^{\circ} \mathrm{C}\right)$ in the dark.

Information such as the obtained in this study helps to understand the reproductive processes that take place in S. mombin. It can be useful in the implementation 
and maintenance of crops and breeding programs, as it will facilitate the choice of adequate individuals for intra- and interspecific crosses.

\section{SUBMISSION STATUS}

Received: 6 sep., 2018

Accepted: 4 feb., 2019

\section{CORRESPONDENCE TO}

\section{Kelli Évelin Müller Zortéa}

Departamento de Ciências Biológicas, Universidade do Estado de Mato Grosso UNEMAT, Avenida Perimetral Rogério Silva, s/n, Bairro Flamboyant, CEP 78580-000, Alta Floresta, MT, Brasil. e-mail: kellimuller@hotmail.com

\section{FINANCIAL SUPPORT}

FAPEMAT (Project: Conservação e uso de espécies vegetais nativas da região Amazônica com potencial econômico para região Norte do estado de Mato Grosso. Process n. 166159/2014) and CAPES.

\section{REFERENCES}

Agostini K, Lopes AV, Machado IC. Recursos florais. In: Rech AR, Agostini K, Oliveira PE, Machado IC, editors. Biologia da polinização. Rio de Janeiro: Projeto Cultural; 2014. 517 p

Alexander MP. A versatile stain for pollen fungi, yeast and bacteria. Stain Technology 1980; 55(1): 13-18. http:// dx.doi.org/10.3109/10520298009067890. PMid:6158141.

Arenas-de-Souza MD, Silveira GF, Silva MAS, Karsburg IV. Estimativa da viabilidade polínica em indivíduos de Tabebuia impetiginosa e Tabebuia crysotricha (Mart. ex. DC.) Standl. (Bignoniaceae) através de métodos citoquímicos. Enciclopédia Biosfera 2014; 10(18): 3864-3871.

Cassimiro CM, Macêdo LS, Menino IB. Avaliação de acessos de cajazeira (Spondias mombin) no Banco Ativo de Germoplasma da Emepa, PB. Tecnologia e Ciência Agropecuária 2009; 3: 1-6.

Cruz CD. Genes - a software package for analysis in experimental statistics and quantitative genetics. Acta Scientiarum Agronomy 2013; 35(3): 271-276. http://dx.doi. org/10.4025/actasciagron.v35i3.21251.

Dafni A. Pollination ecology: a pratical approch. New York: Oxford University Press; 1992. 250 p.
Damasceno PC Jr, Pereira TNS, Freitas M No, Pereira MG. Meiotic behavior of Carica papaya and Vasconcellea monoica. Caryologia 2010; 63(3): 229-236. http://dx.doi. org/10.1080/00087114.2010.10589732.

Diegues IP, Damasceno PC Jr, Ribeiro NVS, Reis MVM, Abboud ACS. Comportamento meiótico e viabilidade polínica na espécie Jatropha curcas L. Semina: Ciências Agrárias 2015; 36(1): 141-150. http://dx.doi.org/10.5433/16790359.2015v36n1p141.

Frazon RC, Raseira MCB, Wagner A Jr. Germinação in vitro de pólen de guabirobeira (Campomanesia xanthocarpa BERG). Revista Ceres 2006; 53(305): 129-134.

Gaaliche B, Majdoub A, Trad M, Mars M. Assessment of pollen viability, germination, and tube growth in eight tunisian caprifig (Ficus carica L.) cultivars. ISRN Agronomy 2013; 2013: 1-4. http://dx.doi.org/10.1155/2013/207434.

Guerra M, Souza MJ. Como observar cromossomos: um guia de técnicas em citogenética vegetal, animal e humana. Ribeirão Preto: FUNPEC; 2002. 131 p.

Hister CAL, Tedesco SB. Estimativa da viabilidade polínica de araçazeiro (Psidium cattleianum Sabine) através de distintos métodos de coloração. Revista Brasileira de Plantas Medicinais 2016; 18(1): 135-141. http://dx.doi. org/10.1590/1983-084X/15_081.

Hoffmann GM, Varassin IG. Variação da viabilidade polínica em Tibouchina (Melastomataceae). Rodriguésia 2011; 62(1): 223-228. http://dx.doi.org/10.1590/21757860201162115

Jesus LGA, Tavares LR, Gomes MFC, Valente SES, Gomes RLF, Lopes ACA et al. Eficiência de testes colorimétricos para determinação da viabilidade do pólen em acessos de feijão-fava (Phaseolus lunatus L). Revista Brasileira de Agropecuária Sustentável 2018; 8(1): 59-64. http://dx.doi. org/10.21206/rbas.v8i1.430.

Kiihl PRP, Barragan MF, Santos SP, Godoy SM, AlonsoPereira AR, Stenzel NMC et al. Abnormal behavior of spindle during microsporogenesis of Passiflora (Passifloraceae). Arquivos de Ciências da Saúde da UNIPAR 2010; 14(3): 237 243. http://dx.doi.org/10.25110/arqsaude.v14i3.2010.3666.

Love RM. Varietal differences in meiotic chromosomes behavior of Brazilian wheats. Agronomy Journal 1951; 43(2): 72-76. http://dx.doi.org/10.2134/agronj1951.000 21962004300020005x.

Macêdo FIA. Identificação da Região Organizadora Nucleolar (NOR) e estabelecimento de protocolo de propagação in vitro de Spondias mombin L. (Anacadiaceae) [Trabalho de Conclusão de Curso]. Alta Floresta: Universidade do Estado de Mato Grosso; 2011

Martins KC, Pereira TNS, Souza SAM, Costa FR. Meiose e viabilidade polínica em acessos de 1746-1751 e Capsicum baccatum. Ciência Rural 2010b; 40(8): 1746-1751. http:// dx.doi.org/10.1590/S0103-84782010000800012. 
Martins KC, Souza SAM, Cuchiara CC. Morfologia polínica: aplicações, estudos e metodologias. 1. ed. Rio de Janeiro: CBJE; 2010a. 75 p.

Mattietto RA, Lopes AS, Menezes HC. Caracterização física e físico-química dos frutos da cajazeira (Spondias mombin L.) e de suas polpas obtidas por dois tipos de extrator. Brazilian Journal of Food Technology 2010; 13(3): 156-164. http://dx.doi.org/10.4260/BJFT2010130300021.

Mitchell JD, Daly DC. A revision of Spondias L. (Anacardiaceae) in the Neotropics. PhytoKeys 2015; 55(55): 1-92. http:// dx.doi.org/10.3897/phytokeys.55.8489. PMid:26312044.

Nadia TL, Machado IC, Lopes AV. Polinização de Spondias tuberosa Arruda (Anacardiaceae) e análise da partilha de polinizadores com Ziziphus joazeiro Mart. (Rhamnaceae), espécies frutíferas e endêmicas da caatinga. Revista Brasileira de Botanica. Brazilian Journal of Botany 2007; 30(1): 89100. http://dx.doi.org/10.1590/S0100-84042007000100009.

Nascimento D, Sbais PG, Alonso-Pereira AR, Canto AF, Romagnolo $\mathrm{MB}$, Alberton $\mathrm{O}$ et al. Analysis of meiotic behavior in Cordia ecalyculata Vell. (Boraginaceae). Biotemas 2014a; 27(4): 21-27. http://dx.doi.org/10.5007/2175$7925.2014 \mathrm{v} 27 \mathrm{n} 4 \mathrm{p} 21$

Nascimento LS, Benevenuti AS, Leite DM, Silva DD, Moura EA, Miranda D et al. Estimativa da viabilidade polínica e índice meiótico de Delonix regia. Estudos 2014b; 41: 83-88. http://dx.doi.org/10.18224/est.v41i0.3854.

Nogueira PV, Silva DF, Pio R, Silva PAO, Bisi RB, Balbi RV. Germinação de pólen e aplicação de ácido bórico em botões florais de nespereiras. Bragantia 2015; 74(1): 9-15. http://dx.doi.org/10.1590/1678-4499.0264.

Oliveira MO, Souza FX, Freitas BM. Abelhas visitantes florais, eficiência polinizadora e requerimentos de polinização na cajazeira (Spondias mombin). Revista acadêmica. Ciências Agrárias e Ambientais 2012; 10(3): 277-284. http://dx.doi.org/10.7213/academica.7711.

Oliveira PE, Maruyama PK. Sistemas reprodutivos. In: Rech AR, Agostini K, Oliveira PE, Machado IC, editors. Biologia da polinização. Rio de Janeiro: Projeto Cultural; 2014. 517 p.

Pagliarini MS. Meiotic behavior of economically important plant species: the relationship between fertility and male sterility. Genetics and Molecular Biology 2000; 23(4): $997-$ 1002. http://dx.doi.org/10.1590/S1415-47572000000400045.

Patel RG, Mankad AU. In vitro pollen germination - A review. International Journal of Scientific Research 2014; 3(5): 304-307.

Pereira TNS, Geronimo IGC, Rossi AAB, Pereira MG. Passiflora cristalina and Passiflora miniata: meiotic characterization of two wild species for use in breeding. Crop Breeding and Applied Biotechnology 2017; 17(3): $267-$ 273. http://dx.doi.org/10.1590/1984-70332017v17n3n41.

Pozzobon MT, Bianchetti LB, Santos S, Carvalho SIC, Reifschneider JB et al. Comportamento meiótico em acessos de Capsicum chinense Jacq. do Banco de Germoplasma da Embrapa, Brasil. Revista Brasileira de Biociências 2015; 13(2): 96-100.
Reis RV, Morais-Lino LS, Silva SO, Amorim EP, Ledo CAS, Viana AP. Variabilidade in vitro de grãos de pólen de bananeira sob diferentes concentrações de ácido bórico e sacarose. Ciência e Agrotecnologia 2011; 35(3): 547-553. http://dx.doi.org/10.1590/S1413-70542011005000001.

Santos MRA, Ferreira MGR, Rocha JF, Correia AO. Estabelecimento de protocolo para germinação de pólen de Musa velutina $\mathrm{H}$. Wendl. \& Drude. Plant Cell Culture \& Micropropagation 2011; 7(1): 22-29.

Santos OD No, Karsburg IV, Yoshitome MY. Variabilidade e germinabilidade polínica de populações de jurubeba (Solanum paniculatum L.). Revista de Ciências AgroAmbientais 2006; 4(1): 67-74.

Shamina NV. A catalogue of abnormalities in the division spindles of higher plants. Cell Biology International 2005; 29(5): 384-391. http://dx.doi.org/10.1016/j.cellbi.2005.02.004. PMid:15982905.

Silva ALG, Pinheiro MCB. Biologia floral e da polinização de quatro espécies de Eugenia L. (Myrtaceae). Acta Botanica Brasílica 2007; 21(1): 235-247. http://dx.doi.org/10.1590/ S0102-33062007000100022.

Souza FX, Costa JTA, Lima RN. Características morfológicas e fenológicas de clones de cajazeira cultivados na Chapara do Apódi, Ceará. Ciência Agronômica 2006; 37(2): 208-215.

Souza MM, Pereira TNS. Meiotic behavior in wild and domesticated species of Passiflora. Revista Brasileira de Botanica. Brazilian Journal of Botany 2011; 34(1): 63-72. http://dx.doi.org/10.1590/S0100-84042011000100007.

Souza MM, Pereira TNS, Martins ER. Microsporogênese e microgametogênese associadas ao tamanho do botão floral e da antera e viabilidade polínica em maracujazeiroamarelo (Passiflora edulis Sims f. flavicarpa Degener). Ciência e Agrotecnologia 2002; 26(6): 1209-1217.

Souza MM, Pereira TNS, Viana AP, Pereira MG, Bernacci LC, Sudré CP et al. Meiotic irregularities and pollen viability in Passiflora edmundoi Sacco (Passifloraceae). Caryologia 2014; 56(2): 161-169. http://dx.doi.org/10.1 080/00087114.2003.1010589320.

Tiburski JH, Rosenthal A, Deliza R, Godoy RLO, Pacheco S. Nutritional properties of yellow mombin (Spondias mombin L.) pulp. Food Research International 2011; 44(7): 2326-2331. http://dx.doi.org/10.1016/j.foodres.2011.03.037.

Zambon CR, Silva LFO, Pio R, Figueiredo MA, Silva KN. Estabelecimento de meio de cultura e quantificação da germinação de grãos de pólen de cultivares de marmeleiros. Revista Brasileira de Fruticultura 2014; 36(2): 400-407. http://dx.doi.org/10.1590/0100-2945-095/13.

Zanotto M, Brammer SP, Nascimento A Jr, Scagliusi SM. Viabilidade polínica como seleção assistida no programa de melhoramento genético de triticale. Ciência e Agrotecnologia 2009; 33(spe): 2078-2082. http://dx.doi. org/10.1590/S1413-70542009000700064.

Zen DM, Acra LA. Biologia floral e reprodutiva de Agapanthus africanus (L.) Hoffmanns (Liliaceae). Estudos de Biologia 2005; 27(59): 35-39. http://dx.doi.org/10.7213/ reb.v27i59.22710. 